\section{SAFETY OF THE WATER JET}

Jan Kmec, Lydia Sobotova and Peter Demec

The Department of Technologies and Materials,

The Faculty of Mechanical Engineering, Technical University in Kosice,

Kosice, The Slovak Republic

e-mail: jan.kmec@tuke.sk

Water - jet cutting technology presents new accesses of shape cutting and various material separations at cold cut without heat influence to material on cutting edge.

Keywords

Water-jet cutting technology, cold cut, all materials

\section{Introduction}

Water-jet cutting technology represents unique, for the future orientated possibility of high automation introduction at high-speed cutting really all material types.

In 30-thy year's American and Russian engineers first time tried to use water stream in mining, demarcating by high speed and that for coal, stone and rock mining.

In the end of 60-thy year's one American airplane producer decided, that he use water jet cutting for processing of fleeced bonded textiles, plastic materials and materials folded from more layers.

High-pressure cutting with water stream, which is named also Water jet-Cutting, was afterwards continuously developed. Important impulse for water jet using in production technique like tool has came from aircraft designing and cosmonautics.

2. Technology WaterJet - safety work with water-jet The water-jet cutting principle is visible on following Fig. 1.

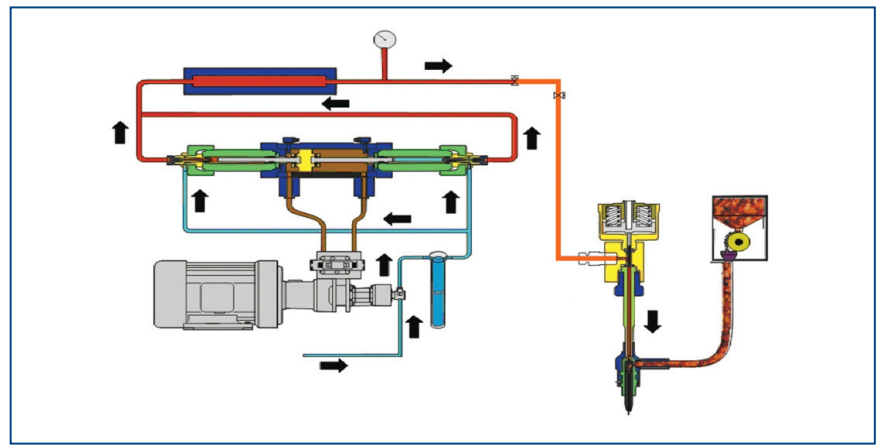

Figure 1. The principle of water-jet cutting - hydro-abrasive method

Safety processes and safety practices of water jet technology must be monitored during introducing to the operation, during lonely operation and maintenance of high pressure pumps. In this area has created tables and symbolic descriptions used in real practice, which is needed to follow at operation of workplaces for water jet material separation. The Tab. 1 shows the most important symbolic descriptions of water jet

The Tab. 2 explains the warning label precautions at water jet operations. The great injuries can be made also when the machine does not work, but the pump system was not switch off. After following starting of work on machine, the high pressure of water jet can injure the person as cutting injuries.

In the Tab. 3 is shown the important symbols from the point of view of maintenance and service.

Table 3. Warning Label Precautions

\begin{tabular}{|c|c|}
\hline$\triangle 1$ CAUTION & $\begin{array}{l}\text { Show on dangerous, which can cause personal injuries } \\
\text { or property damage, if care instructions are ignored. }\end{array}$ \\
\hline$\triangle 1$ WARNING & $\begin{array}{c}\text { Show on dangerous, which can cause serious } \\
\text { personal injuries, death or substantial property damage, } \\
\text { if warning is ignored. }\end{array}$ \\
\hline & $\begin{array}{l}\text { High pressure of water stream can cause eyes injuries. } \\
\text { Protect your eyes, when you work near the machine. }\end{array}$ \\
\hline & $\begin{array}{l}\text { Dangerous noise can cause hearing loss } \\
\text { Protect your ears, if you work near the machine. }\end{array}$ \\
\hline & $\begin{array}{l}\text { Dangerous electric tension can cause iniury or death. } \\
\text { Before opening the case unplug and disconnect }\end{array}$ \\
\hline & Wrong function \\
\hline & Hydraulic multipliers \\
\hline & Pressure control \\
\hline How & High pressure \\
\hline$\rightarrow$ & Low pressure \\
\hline 1 & Start/Initialization \\
\hline & Stop \\
\hline & Running \\
\hline
\end{tabular}

Table 1. Tables and abbreviations for safety at work with water-jet

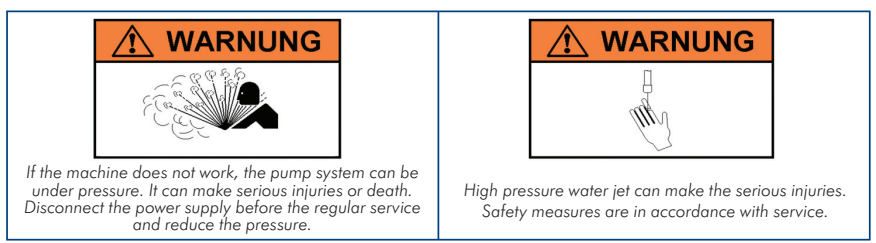

Table 2. Warning Label Precautions

The electrical enclosure and motor junction box can
present an electrical shock hazard.
Always disconnect and lockout the main power before
opening the enclosure. You must always disconnect and
lockout the main power and the circuit disconnect on the
electrical enclosure door before performing any type
of maintenance.

Table 3. Warning Label Precautions 


\section{Safety processes}

Safety procedures must be following while it is worked with high pressure pump, with some its high pressure part. Such pump can operate only by qualified person. It is concerned at following safety procedures:

- High pressure of water from 3800 to 4150 bar (55 to 60000 psi) at water-jet cutting systems should not be reason for disconcertment. User must have respect before that pressure and use current safety processes and safety working practices.

- Everyone, who is connected with water-jet cutting system must realize, that power of water-jet cutting stream can penetrate into many hard and strong materials.

- Not qualified personal must not move in water-jet cutting area.

- In water-jet cutting area must be all time used safety glasses and earmuffs.

- All emergency STOP buttons must be regularly checked. During normal operation are pulled out.

- Check of buttons: Turn on electric supply and activate emergency STOP button so, that are pushed, you must see, if energy exploding. Every device should be checked according special table. All the time, when device is checked, must function or must be returned into the original status before the start of operation.

- Use high clean lubricating wax for all threaded high-pressure connections. All piping, assembled and screwed connections should be tightened into the recommended moment values. If the circuit is under high pressure, do not try tight or install any high pressure parts, see safety of high pressure tubing.

- All high pressure leakages must be immediately repaired.

- Check all equipment according tables.

- Before maintenance starting, turn off the main stop and ensure that high pressure is released.

In the Tab. 4 are shown the warnings of water jet operations.

\begin{tabular}{|l|l|}
\hline DARNING & $\begin{array}{l}\text { Never perform any work on device without that you have } \\
\text { guarantee that electric panel is unplugged. }\end{array}$ \\
\hline WARNING & $\begin{array}{l}\text { Never work on any part with high pressure or released } \\
\text { high pressure connections without that you firstly released } \\
\text { the system and ensure that there is not high pressure. }\end{array}$ \\
\hline WARNING & $\begin{array}{l}\text { Ensure that safety devices are in the operation. At dangerous } \\
\text { stop the pump and unplugged high pressure. Emergency } \\
\text { STOP buttons must be pushed. Pressure valve system must } \\
\text { be opened. }\end{array}$ \\
\hline WARNING & $\begin{array}{l}\text { Do not try to touch or be exposed to high pressure water. } \\
\text { High pressure water penetrates into all parts of human body } \\
\text { without exceptions. }\end{array}$ \\
\hline WARNING & $\begin{array}{l}\text { Dropping water or material produced by this extreme } \\
\text { pressure can injury or kill. }\end{array}$ \\
\hline
\end{tabular}

Table 4. Warnings at water jet operations

\section{Safety of the high pressure tubing}

Tubing with high pressure must be installed without stress in torsion. Suitable support and direction must be ensured. 9/16" external diameter of high pressure pipes and armatures are recommended between the pump and the cutting head. Tubes of these big dimensions will decrease vibration, tension and bend between pump tubing and cutting area. Bigger tubing diameter also decreases the pressure and pressure pulsation.

In the Tab. 5 are shown the warning, which are connecting with the work and manipulation.

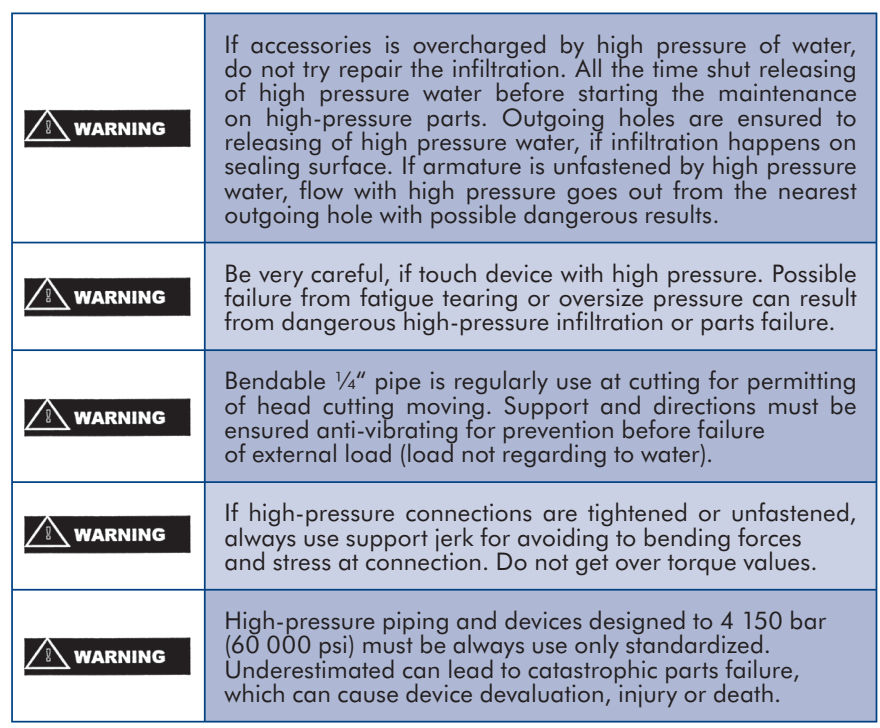

Table 5. Safety at work and manipulation with water jet

\section{General maintenance \\ from point of view of work safety}

Suitable maintenance is importantfor reliable and rigorous performance. Preventive maintenance reduces stoppage time for repairing, provides bigger operating life of parts and increases work safety.

High-pressure water will cut almost all what touches. Every infiltration must be immediately repaired to prevent damage or serious personal injury.

\section{Maintenance directions are following:}

- Regular equipment checking is recommended,

- Keep equipment and surroundings clear,

- Check pressures, temperatures and seal tightness,

- Immediately execute repairing,

- Maintenance record should be saved.

\section{Working environment at water jet operations:}

- Keep clear working environment for repair and maintenance waterjet pump.

- Use clear working table for repairs and clear working environment.

- Use not woolen materials for wiping.

- If parts with compressed air are released, use only clear, dry air. If parts are wash solvent, use only clear filtrated liquid.

- Always use original spare parts from producer for original version, reliability, safety and guarantee protection.

\section{Safety recommendations for working persons:}

- Carefully read the safety instructions.

- Turn off all electric power.

- Shut all incoming delivery valves and open all unwatering valves.

- Shut injection and transfer valves, if energy is closed, safety exiting valve will open and release water high pressure hidden in releasing tubing.

- Ensure suitable drawer, bowl, tanks, etc. For fixation and detention liquid to avoid of hazardous working environment.

- Abide double control for ensuring, that all pressure is removed from system before you continue in work.

- Especially medical treatment is required always at treatment of wounding by wateriet according to card for emergency rescue. This card is part of technology delivery.

- Avoid of leaking, sharpen abrasions or bend loads, if work with expensive technology parts.

- Ensure, that all parts are clean, without sharpen edges, particulates, dirt, etc. 
- Use high clean lubricant wax, if assemble some high pressure part or set.

- After repair any high-pressure part, check all high pressure connections for releasing of pressure.

\section{Conclusions}

Work safety with water-jet in various production technologies must make provision for not only safety work with water-jet technology, but also safety work with all devices, which are on that workplace situated and also material manipulation. In case of other workplace devices, manipulation with material, interoperable transport, storage, control and overall work environment, i.e. production logistic, safety regulations valid for technology operation are applied and followed, in accordance with law, in terms of Inspectorate of work safety and State health authority.

\section{Acknowledgements}

The contribution was prepared in the frame of solving of grant scientific project VEGA No. 1/0396/11.

\section{References}

[Kmec 2009] Kmec,J., Sobotova,L. Dividing of Hydroerosion Jet. 1 eletrinic optical disc (CD-ROM).In: Trends and Inovative Accesses in corporatived processes .In: 12. International Scietific Conference: Proceeding of contributions in eletronic form (in Slovak): Kosice, December 2009. - Kosice: Technical University, Faculty of Mechanical Engineering, 2009, p. 1-5. ISBN 978-80-553-0330-7

[Kmec 2010a] Kmec,J., Sobotova,L. Water Jet 25 years in Slovakia. In: Transfer Inovation. No. 18 (2010),p. 160-164. (in Slovak) ISSN 1337-7094. Form of entry: /_www.sjf.tuke.sk/transfer-inovacii/ <http://www.sjf.tuke.sk/transfer-inovacii/

[Kmec 2010b] Kmec,J., Sobotova,L. Bicejova,L.: Categories of parameters influences on hydroerosion. 1 eletrinic optical disc (CD-ROM).In: Trends and Inovative Accesses in corporatived processes: 13. International Scietific Conference.(in Slovak) Kosice: Technical University, Faculty of Mechanical Engineering, 2010 p. 1-10. ISBN 978-80-553-0570-7

[Kmec 2011] Kmec,J., Sobotova,L. Progressive Dividing by Hydroerosion. (in Slovak) In: Mechanical technology- Pilsen 2011: IV. International Conference: 25. - 26- th January 2011: Pilsen, Czech Republic. p. 1-6. ISBN 978-80-7043-934-0

[Pacaiova 2009] Pacaiova, H., Sinay, J. And Glatz, J. Safety and risks of technological systems. (in Slovak) Kosice: Faculty of Mechanical Engineering Technical University in Kosice, 2009. ISBN 978-80-553-0180-8

\section{Contacts}

doc. Ing. Jan Kmec, CSc.

Technical University in Kosice

The Faculty of Mechanical Engineering

The Department of Technologies and Materials

Mäsiarska 74, 04001 Kosice, The Slovak Republic

tel.: 00421/556 023 515,e-mail: jan.kmec@tuke.sk

doc. Ing. Lydia Sobotova, PhD.

Technical University in Kosice

The Faculty of Mechanical Engineering

The Department of Technologies and Materials

Mäsiarska 74, 04001 Kosice, The Slovak Republic

tel.: 00421/556 023 518, e-mail: lydia.sobotova@tuke.sk

prof. Ing. Peter Demec, CSc.

Technical University in Kosice

The Faculty of Mechanical Engineering

The Department of Manufacturing engineering and robotics

Mäsiarska 74, 04001 Kosice, The Slovak Republic

e-mail: peter.demec@tuke.sk 